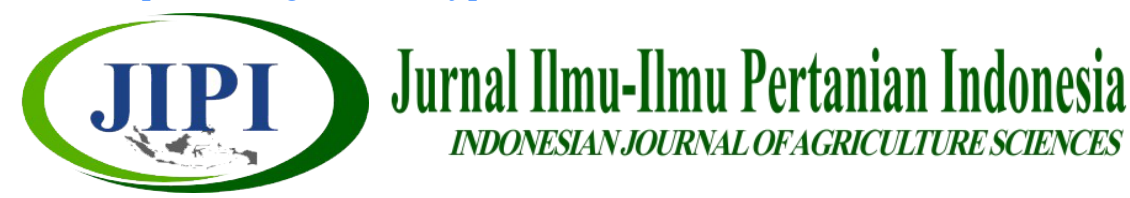

\title{
EFEK KONSENTRASI DAN WAKTU APLIKASI PUPUK ORGANIK CAIR KULIT PISANG TERHADAP PERTUMBUHAN DAN HASIL TANAMAN KUMIS KUCING (Orthosiphon aristatus)
}

\author{
Detri Saputra $^{1}$, Entang Inoriah Sukarjo $^{1^{*}}$, Masdar $^{1}$ \\ ${ }^{1}$ Program Studi Agroekoteknologi, Fakultas Pertanian Universitas Bengkulu \\ * Corresponding Author: einoriah@unib.ac.id
}

\begin{abstract}
[THE EFFECT OF CONCENTRATION AND APPLICATION TIME OF LIQUID ORGANIC FERTILIZER FROM BANANA PEELS ON GROWTH AND YIELD OF JAVA TEA (Orthosiphon aristatus)]. Java tea is a medicinal plant that has many health benefits. One way to increase the growth and yield of java tea is by using liquid organic fertilizer (LOF) from banana peels. This study was aimed to evaluate the concentration and application time of LOF from banana peels on the growth and yield of java tea. The study was conducted in Bengkulu from November 2018 to February 2019. The experiments were arranged in a completely randomized design with factorial combination between the two factors, including LOF concentration of banana peels of $25,50,75$, and $100 \mathrm{~mL} / \mathrm{L}$; and time of LOF application which consists of 1,2, and 3 times of application in a week. The results showed that concentration and application time and the interactions did not significantly influence the observed variable including the thickness of leaves, total leaf area, shoot length, number of leaves, fresh plant weight, root length, and dry plant weight.
\end{abstract}

Keyword: application time, concentration, liquid organic fertilizer, java tea

\begin{abstract}
ABSTRAK
Kumis kucing merupakan tanaman obat yang memiliki banyak khasiat untuk kesehatan namun produksi tanaman kumis kucing sangat rendah. Upaya yang dilakukan untuk meningkatan pertumbuhan dan hasil kumis kucing yaitu dengan penggunaan pupuk organik cair (POC) kulit pisang. Penelitian ini bertujuan untuk mendapatkan konsentrasi, waktu aplikasi POC kulit pisang, dan interaksi antara keduanya yang menghasilkan pertumbuhan dan hasil tanaman kumis kucing yang tinggi. Penelitian dilaksanakan mulai bulan November 2018 hingga Februari 2019 di Kota Bengkulu. Percobaan disusun berdasar Rancangan acak lengkap pola faktorial. Faktor pertama konsentrasi POC kulit pisang $25 \mathrm{ml} / \mathrm{L}, 50 \mathrm{ml} / \mathrm{L}, 75 \mathrm{ml} / \mathrm{L}$, dan $100 \mathrm{ml} / \mathrm{L}$. Faktor kedua adalah waktu aplikasi POC yang terdiri atas 1 minggu sekali aplikasi, 2 minggu sekali aplikasi, dan 3 minggu sekali aplikasi. Hasil penelitian menunjukkan bahwa secara mandiri pemberian konsentrasi dan waktu aplikasi maupun interaksinya berpengaruh tidak nyata terhadap variabel tebal daun, luas daun total, panjang tunas, jumlah daun, bobot tanaman segar, panjang akar, dan bobot tanaman kering.
\end{abstract}

Kata kunci: konsentrasi, kumis kucing, pupuk organik cair, waktu aplikasi 


\section{PENDAHULUAN}

Indonesia merupakan negara penghasil sumber hayati terbesar kedua di dunia, Salah satunya komoditas biofarmaka potensial adalah tanaman kumis kucing (Direktorat Jendral Perkebunan, 2017). Tanaman kumis kucing (Orthosiphon aristatus [(Blume.) MiQ.)] merupakan tanaman yang mampu tumbuh pada dataran rendah hingga ke dataran menengah $550 \mathrm{~m}$ dpl (Rostiana, 2012).

Tanaman kumis kucing merupakan tanaman obat asli Indonesia yang sering digunakan dalam pengobatan tradisional. Daun kumis kucing ini dapat digunakan masyarakat untuk menyembuhkan batuk, encok, masuk angin, sembelit, radang ginjal dan batu ginjal (Direktorat Pengolahan dan Pemasaran hasil pertanian, 2013). Bagian tanaman kumis kucing yang dimanfaatkan berupa daunnya karena daun kumis kucing mengandung ortosiponin glikosida, minyak atsiri, garam kalium dan sinensin (BPOM RI, 2004). Tanaman kumis kucing diperbanyak dengan cara vegetatif yaitu berasal dari stek batang. Kriteria tanaman kumis kucing yang dijadikan bibit adalah batang atau cabang sehat dan tidak terlalu tua maupun muda, dengan panjang stek $15 \mathrm{~cm}-20 \mathrm{~cm}$ atau memiliki 2-3 buku (Hajoeningtijas \& Budi, 2008).

Pada tahun 2016 lahan budidaya kumis kucing di Jawa Barat sangat sedikit yaitu 217 ha dengan produksi 55 ton (BPS Jawa Barat, 2016). Sementara untuk di Bengkulu sendiri tanaman kumis kucing belum dibudidayakan secara alternatif. Adapun permasalahan utama dalam budidaya kumis kucing kurangnya modal petani dan saprodi sementara terjadi fruktuasi harga jual simplisia. (Pribadi et.al., 2014).

Tanaman kumis kucing membutuhkan unsur hara yang cukup untuk meningkatkan produksinya. Unsur hara tersebut dapat berasal dari bahan organik dan anorganik. Limbah kulit pisang dapat dijadikan sebagai bahan sumber pembuatan pupuk organik cair (POC). Kulit pisang dalam bentuk pupuk organik cair mengandung unsur hara $\mathrm{N}, \mathrm{P}$, dan $\mathrm{K}$ yang sudah memenuhi SNI (Nasrun et.al.,2016). POC mengandung $\mathrm{K}_{2} \mathrm{O}$ yang tinggi yaitu sebesar 9,45\% (Nugraha, 2013).

Penggunaan POC kulit pisang dapat meningkatkan kandungan protein tanaman kangkung (Parawansa \& Hamka, 2014). Penelitian lainnya juga menunjukkan bahwa pemberian pupuk cair kulit pisang kepok 25 $\mathrm{mL}$ nyata pengaruhnya terhadap pertumbuhan tanaman sawi setelah pindah tanam 11-29 hari (Nasution et al., 2014). Penggunaan POC kulit pisang pada konsentrasi 2 $\mathrm{mL} / \mathrm{L}$ air mampu memperbaiki pertumbuhan dan hasil kedelai (Masayu, 2015). Konsentrasi 20 mL/tanaman merupakan konsentrasi terbaik untuk pertumbuhan tanaman bayam (Sari, 2014). Demikian pula pemberian POC kulit pisang juga mampu meningkatkan produksi tanaman kakao (Agusimar, 2016). Waktu aplikasi POC bio-slurry (2 mst dan $4 \mathrm{mst}$ ) mampu menunjukkan peningkatan pertumbuhan dan hasil kacang tanah yang ditunjukkan oleh tinggi tanaman, jumlah daun, jumlah cabang, bobot berangkasan kering tanaman, dan bobot/petak panen (Safei, 2018).

Penelitian ini bertujuan untuk mendapatkan konsentrasi, waktu aplikasi POC kulit pisang dan interaksi antara keduanya terhadap pertumbuhan tanaman kumis kucing.

\section{METODE PENELITIAN}

Penelitian ini telah dilaksanakan pada bulan November 2018 hingga Februari 2019 di Padang Harapan, Kota Bengkulu dengan menggunakan Rancangan Acak Lengkap (RAL) pola faktorial. Faktor pertama adalah konsentrasi larutan yang terdiri atas empat taraf yaitu $25 \mathrm{~mL} / \mathrm{L}\left(\mathrm{k}_{1}\right), 50 \mathrm{~mL} / \mathrm{L}\left(\mathrm{k}_{2}\right), 75 \mathrm{~mL} / \mathrm{L}\left(\mathrm{k}_{3}\right)$, dan $100 \mathrm{~mL} / \mathrm{L}\left(\mathrm{k}_{4}\right)$. Faktor kedua adalah waktu aplikasi yang terdiri atas tiga taraf yaitu 1 minggu sekali aplikasi $\left(\mathrm{w}_{1}\right), 2$ minggu sekali aplikasi $\left(\mathrm{w}_{2}\right)$, dan 3 minggu sekali aplikasi $\left(\mathrm{w}_{3}\right)$. Dari kedua faktor tersebut diperoleh 12 kombinasi perlakuan yang diulang sebanyak 3 kali sehingga diperoleh 36 satuan percobaan.

Bahan tanaman yang digunakan adalah batang atau cabang tanaman yang sehat dengan panjang stek 2-3 ruas yang dilakukan selama 14 hari atau sampai bibit sudah memliki dua buah tunas.

Persiapan media tanaman diawali dengan persiapan polybag, pengambilan Ultisol kemudian dicampur dengan pupuk kandang dengan volume 2:1. POC kulit pisang dibuat dengan mempersiapkan $10 \mathrm{~kg}$ kulit pisang yang telah dipotong-potong dan ditumbuk sampai halus. Kulit pisang yang telah halus dimasukan ke dalam jerigen, kemudian ditambahkan $10 \mathrm{~L}$ air, $250 \mathrm{~g}$ gula, $250 \mathrm{~mL}$ EM4 dan diaduk sampai rata, selanjutnya jerigen tersebut ditutup rapat dan di inkubasi selama 14 hari. Setiap hari tutup jerigen dibuka untuk mengeluarkan gas yang ada di dalam wadah. Setelah fermentasi sempurna POC kulit pisang siap diaplikasikan ke tanaman.

Penanaman dilakukan pada saat bibit telah memiliki dua buah tunas, Bibit dipindah kan ke lubang tanam pada media di dalam polybag dengan volume $30 \mathrm{~cm}$ x $25 \mathrm{~cm}$. Penyulaman dilakukan 1 minggu setelah tanam (mst) pada tanaman yang mati atau tidak tumbuh optimal dengan bibit yang berumur sama.

Pupuk yang digunakan yaitu pupuk organik cair (POC) kulit pisang yang diaplikasikan sesuai dengan konsentrasi perlakuan $(25,50,75$, dan $100 \mathrm{~mL} / \mathrm{L}$ air $)$ dan waktu aplikasi (1, 2, 3 minggu dan kontrol). Penyiraman dilakukan satu kali sehari pada saat pembibitan dan pemeliharaan, apabila cuaca cerah atau panas terik maka diberikan penyiraman tambahan untuk menambah kelembaban pada tanah.

Penyiangan dilakukan dengan cara mencabut gulma yang tedapat pada polybag percobaan dengan tangan dan arit, kemudian dilanjutkan dengan pengendalian gulma yang terdapat pada lingkungan sekitar agar tidak 
terjadi perebutan unsur hara terhadap tanaman kumis kucing.

Tanaman kumis kucing dipanen setelah berumur 4 mst. Pemanenan taman kumis kucing dilakukan dengan cara memotong pucuk daun 3-5 helai kemudian merempel daun di bawahnya.

Data yang dikumpulkan dianalsis secara statistik dengan uji $\mathrm{F}$ pada taraf $5 \%$ apabila pada perlakuan yang menunjukkan perbedaan nyata maka dilakukan BNT pada taraf $5 \%$.

\section{HASIL DAN PEMBAHASAN}

Secara umum tampilan tanaman mulai di tingkat persemaian hingga di pertanaman pot percobaan pertumbuhannya relatif seragam dan sehat. Namun pertumbuhan menjadi melambat, bahkan pada umur 1,5 bulan tanaman sudah menunjukkan kemunculan bunga. Kondisi ini kurang lazim pada fase tersebut yang seharusnya didominasi oleh pertumbuhan vegetatif, dibandingkan dengan budidaya tanaman kumis kucing pada umumnya umur 3 bulan baru berbunga. Pada saat di pertanaman tanaman kumis kucing tidak terserang hama maupun penyakit, sehingga tanaman tumbuh seluruhnya. Curah hujan selama penelitian berlangsung berkisar antara 149 $590,5 \mathrm{~mm}$ atau rata-rata $402,9 \mathrm{~mm} /$ bulan, rata-rata suhu udara antara $26,5{ }^{\circ} \mathrm{C}-52,6{ }^{\circ} \mathrm{C}$, kelembaban udara antara $83,8 \%-86,2 \%$, intensitas penyinaran matahari antara 49\%-68,9\% (BMKG Pulau Baai, 2019) dan suhu tanah antara $27,1^{\circ} \mathrm{C}-30,4{ }^{\circ} \mathrm{C}$.

Hasil analisis statistik menunjukkan bahwa secara mandiri ataupun interaksi antara konsentrasi dan waktu aplikasi POC berbeda tidak nyata $(\mathrm{P}>0,05)$. Rata-rata pertumbuhan dan hasil tanaman kumis kucing pada empat taraf dan kontrol seperti terlihat pada Tabel 1.
Peningkatan konsentrasi POC hingga $75 \mathrm{~mL} / \mathrm{L}$ air menghasilkan daun yang lebih tebal $(0,36 \mathrm{~mm})$ dibandingkan dengan rata-rata tebal daun pada konsentrasi di bawahnya (Tabel 1). Namun demikian secara statistik tingkat ketebalan daun tidak dipengaruhi $(\mathrm{P}>0,05)$ oleh konsentrasi POC. Ketebalan daun suatu tanaman dipengaruhi oleh proses fotosentesis, banyaknya cahaya matahari yang diserap tanaman yang terutama untuk bagian daun pada intensitas cahaya yang tinggi dapat mempengaruhi ketebalan daun (Sitompul \& Guritno, 1995).

Luas daun total yang diamati memiliki pola kenaikkan yang mirip dengan ketebalan daun. Konsentrasi $75 \mathrm{ml} / \mathrm{L}$ air juga menghasilkan luas daun total yang lebih luas dibandingkan dengan konsentrasi kurang atau lebih dari $75 \mathrm{~mL} / \mathrm{L}$ air. Hal ini diduga pada konsentrasi $100 \mathrm{ml} / \mathrm{L}$ air memberikan respon negatif terhadap pertumbuhan dan hasil tanaman kumis kucing (Pardosi et al., 2014).

Konsentrasi POC kulit pisang $75 \mathrm{~mL} / \mathrm{L}$ air menghasilkan panjang tunas terpanjang rata-rata $16,95 \mathrm{~cm}$ namun pada konsentrasi $100 \mathrm{ml} / \mathrm{L}$ air justru menghasilkan panjang tunas terpendek. Pemberian MOL kulit pisang kepok $300 \mathrm{~mL} /$ tanaman menghasilkan rata-rata tinggi tanaman kedelai $17,42 \mathrm{~cm}$ yang berbeda tidak nyata dengan perlakuan kontrol (Palupi, 2015). Hasil penelitian Sari (2016) menunjukkan bahwa konsentrasi POC $20 \mathrm{~mL} / \mathrm{L}$ air merupakan konsentrasi terbaik terhadap tanaman bayam, peningkatan konsentrasi hingga $60 \mathrm{~mL} / \mathrm{L}$ air pertumbuhan tanaman menjadi semakin menurun. Penelitian Nasution et al. (2014) menunjukkan bahwa pupuk organik cair dapat menurunkan tinggi tanaman. Hasil yang berbeda ditunjukkan oleh penelitian Makmur \& Magfirah (2018) bahwa konsentrasi POC $70 \mathrm{~mL} / \mathrm{L}$ air menghasilkan tinggi tanaman tertinggi yaitu $41,8 \mathrm{~cm}$. Pemberian pupuk yang kurang atau berlebih akan mempengaruhi pertumbuhan tanaman (Nurhasana, 2011).

Tabel 1. Rata-rata pertumbuhan dan hasil tanaman kumis kucing pada konsentrasi POC.

\begin{tabular}{l|c|c|c|c|c|c|c}
\hline $\begin{array}{c}\text { Konsentrasi } \\
(\mathrm{mL} / \mathrm{L} \text { air) }\end{array}$ & TD (mm) & LDT $\left(\mathrm{cm}^{2}\right)$ & PT $(\mathrm{cm})$ & JD & BST (g) & PA (cm) & BKT (g) \\
\hline 25 & 0,35 & 27,97 & 14,34 & 64,73 & 28,62 & 36,74 & 6,64 \\
\hline 50 & 0,34 & 26,75 & 15,01 & 61,35 & 29,34 & 34,54 & 5,8 \\
\hline 75 & 0,36 & 29,09 & 16,95 & 62,66 & 30,36 & 37,47 & 6,5 \\
\hline 100 & 0,32 & 23 & 12,4 & 55,67 & 24,52 & 38,84 & 7,01 \\
\hline 0 & 0,33 & 23,74 & 14,87 & 47,14 & 23,97 & 28,7 & 8,17 \\
\hline
\end{tabular}


Tanaman membutukan unsur hara makro dan unsur hara mikro dalam jumlah yang cukup namun apabila unsur hara yang diberikan berlebihan makan unsur hara tersebut dapat menghambat pertumbuhan tanaman.

Jumlah daun terbanyak rata-rata 64,73 helai dihasilkan pada konsentrasi POC kulit pisang pada konsentrasi $25 \mathrm{~mL} / \mathrm{L}$ air. Secara rata-rata terlihat bahwa konsentrasi POC kulit pisang dapat meningkatkan jumlah daun. Penggunaan POC yang diberikan berdasarkan kandungan

sebagai unsur luxury consumption. Semakin tinggi status $\mathrm{K}$-tanah dan dosis pupuk $\mathrm{K}$, maka makin tinggi pula residu $\mathrm{K}$ dalam tanah (Rosliani \& Basuki., 2012 ; Husic \& Cicic, 2009). Ada keterkaitan keberadaan unsur $\mathrm{K}$ di dalam tanah dan jaringan tanaman dengan unsur hara lainnya. Kelebihan $\mathrm{N}$ pada tanaman dapat menyebabkan defesiensi unsur $\mathrm{K}$ yang dapat meyebabkan tanaman kerdil (Ruhnayat, 2007).

Konsentrasi POC kulit pisang menghasilkan bobot segar yang hampir sama. Rata-rata bobot segar tertinggi 30,36 g dihasilkan oleh konsentrasi $75 \mathrm{ml} / \mathrm{L}$ air. Banyak faktor yang mempengaruhi kecepatan tumbuh tanaman antara lain lingkungan (nutrisi, suhu, dan kelembaban), dan faktor genetik (hormon) tanaman (Rochman \& Nurwiati, 2005). Penelitian serupa yang dilakukan oleh Apitriani et al. (2016) juga menunjukkan bahwa konsentrasi POC kulit pisang memberikan pengaruh yang tidak nyata terhadap bobot tanaman segar tomat dan bobot segar tanaman sawi (Saragih, 2016). Hasil ini berbeda dengan hasil penelitian Manullang et al. (2014) yang menunjukkan adanya perbedaan nyata antar perlakuan konsentrasi POC.

Bobot tanaman kering mencerminkan indikasi pertumbuhan tanaman selain kemampuan tanaman dalam menyerap unsur hara dari media tanam untuk menunjang pertumbuhannya. Rata-rata bobot tanaman kering tertinggi yaitu $8,17 \mathrm{~g}$ dihasilkan oleh tanaman tanpa pemberian POC. Bobot kering merupakan ukuran pertumbuhan dan perkembangan tanaman karena bobot kering mencerminkan akumulasi senyawa organik yang berhasil disintesis oleh tanaman. Bobot kering tanaman juga mencerminkan status nutrisi suatu tanaman dan juga merupakan indikator yang menentukan baik tidaknya suatu pertumbuhan dan perkembangan tanaman sehingga erat kaitannya dengan ketersediaan hara (Sitorus et al., 2014).

Aplikasi waktu pemberian POC 2 minggu sekali menunjukkan rata -rata ketebalan daun lebih tebal $(0,36 \mathrm{~mm})$ dibandingkan dengan aplikasi kontrol, 1 minggu sekali aplikasi, maupun 3 minggu sekali aplikasi (Tabel 2). Ketebalan daun kumis kucing sangat dipengaruhi oleh karakteristik tanaman itu sendiri sehingga pemberian konsentrasi POC belum mampu mempengaruhi ketebalan daun. Hasil ini berbeda dengan hasil percobaan yang dilakukan sebelumnya bahwa interval waktu 6 hari pemberian POC (kotoran ayam, air kelapa dan daun gamal) mampu meningkatkan serapan $\mathrm{N}$ dan produksi tanaman kailan (Masayu, 2015).

Luas daun total yang dihasilkan oleh aplikasi 3 minggu sekali menunjukkan lebih luas yaitu $30,36 \mathrm{~cm}^{2}$ dibandingkan dengan perlakuan aplikasi lainnya. Interval waktu aplikasi POC kulit pisang memberikan pengaruh yang tidak nyata $(P>0,05)$ terhadap luas daun total tanaman kumis kucing. Hasil penelitian ini sesuai dengan penelitian Daryanti \& Dewi (2017) yang menunjukkan interval pemberian pupuk organik cair (P) belum mampu meningkatkan tinggi tanaman dan luas daun pakchoy. Interval waktu pemberian POC BMW setiap 6 hari juga belum mampu menambah luas daun tanaman sawi secara nyata (Rajak et al., 2016)..

Panjang tunas pada aplikasi 2 minggu sekali menunjukkan rata-rata terpanjang $13,89 \mathrm{~cm}$ jika dibandingkan aplikasi waktu lainnya. Pertumbuhan tanaman kumis kucing tidak dipengaruhi oleh waktu pemberian POC walau seharusnya semakin sering diberi POC maka unsur hara yang dibutuhkan tanaman menjadi tercukupi. Pupuk organik cair mengandung unsur hara $\mathrm{N}$, P,dan $\mathrm{K}$ yang sangat dibutukan untuk proses fisiologi dan metabolisme tanaman agar dapat memicu pertumbuhan suatu tanaman. Hariuddin (2012) menyatakan bahwa unsur hara yang terdapat pada pupuk organik sangat memacu pertumbuhan tunas baru dan pembentukan cabang tanaman. Hasil penelitian lain juga menunjukkan bahwa interval waktu pemberian pupuk organik cair berpengaruh tidak nyata terhadap tinggi tanaman umur 10, 20 dan 30 hst (Jumini et al., 2012).

Jumlah daun terbanyak rata-rata 64,39 helai (Tabel 2) dihasilkan oleh aplikasi POC 2 minggu Tanpa pemberian POC menghasilkan jumlah daun paling sedikit. Setiap tanaman membutuhkan waktu pemberian unsur hara yang berbeda-beda, pemberian pupuk organik cair Cocober Plus dengan interval waktu pemberian satu minggu sekali mampu meningkatkan pertumbuhan dan hasil bawang merah (Jamilah et al.,2017). Sementara hasil penelitian Muldiana \& Rosdiana (2017) menunjukkan pemberian POC dengan pada interval waktu 7 hari berbeda tidak nyata jika dibandingkan perlakuan 3 hari, 5 hari, dan 9 hari.

Aplikasi POC 1 minggu sekali menghasilkan bobot tanaman segar terberat rata-rata $28,50 \mathrm{~g}$ jika dibandingkan dengan waktu aplikasi lainnya. Semakin pendek interval waktu pemberian POC maka unsur hara yang tersedia untuk tanaman lebih banyak sehingga meningkatkan pertumbuhan tanaman. Tanaman membutukan unsur hara $\mathrm{N}$ untuk merangsang pertumbuhan vegetatif tanaman yang pada gilirannya akan meningkatkan bobot tanaman segar (Damanik et al., 2011).

Akar merupakan salah satu bagian terpenting bagi tumbuhan. Akar yang panjang dapat menentukan banyak nya unsur hara yang diserap oleh akar tanaman untuk proses fotosintesis (Wahyono, 2008). 
Tabel 2. Rata-rata pertumbuhan dan hasil tanaman kumis kucing pada waktu aplikasi POC

\begin{tabular}{|c|c|c|c|c|c|c|c|}
\hline $\begin{array}{c}\text { Waktu } \\
\text { (minggu) }\end{array}$ & $\mathrm{TD}(\mathrm{mm})$ & $\begin{array}{l}\text { LDT } \\
\left(\mathrm{cm}^{2}\right) \\
\end{array}$ & PT $(\mathrm{cm})$ & JD & BST (g) & $\mathrm{PA}(\mathrm{cm})$ & $\operatorname{BKT}(\mathrm{g})$ \\
\hline 1 & 0,33 & 28,62 & 13,89 & 59,32 & 28,5 & 36,41 & 6,01 \\
\hline 2 & 0,36 & 29,34 & 15,21 & 64,39 & 27,98 & 38,48 & 6,79 \\
\hline 3 & 0,33 & 30,36 & 14,96 & 59,59 & 28,14 & 35,81 & 6,67 \\
\hline 0 & 0,33 & 23,74 & 14,86 & 47,14 & 23,97 & 28,7 & 8,17 \\
\hline
\end{tabular}

Akar yang panjang juga menunjukkan reaktivitas tanaman yang lebih besar. Panjang akar pada aplikasi 2 minggu menghasilkan rata-rata akar lebih panjang yaitu $38,48 \mathrm{~cm}$

Tanaman kumis kucing yang tidak diberi POC menghasilkan bobot lebih tinggi dibandingkan dengan waktu aplikasi lainnya. Secara umum bahwa aplikasi pemberian POC dapat meningkatkan nilai rata-rata beberapa variabel yang diuji. Artinya aplikasi POC masih memberikan kontribusi untuk pertumbuhan tanaman kumis kucing walau menunjukkan perbedaan yang tidak nyata secara statistik $(\mathrm{P}>$ 0,05). Bobot tanaman kering pada perlakuan aplikasi tanpa diberi POC menunjukkan rata-rata lebih berat dibandingkan dengan perlakuan lainnya. Aplikasi POC dengan frekuensi yang lebih tinggi belum cukup mampu memberi sumbangan yang nyata untuk pertumbuhan tanaman. Berdasarkan kandungan unsur hara penting seperti $\mathrm{N}, \mathrm{P}$, dan $\mathrm{K}$ pada $\mathrm{POC}$ kulit kepok pisang dengan kandungan $\mathrm{N}=0,63 \%$, $\mathrm{P}$ $=0,376 \%$, dan $\mathrm{K}=0,379 \%$ yang relatif rendah. Kebutuhan pupuk tanaman kucing adalah Urea 150 $\mathrm{kg} / \mathrm{ha}$, TSP $100 \mathrm{~kg} / \mathrm{ha}$ dan $\mathrm{KCl} 100 \mathrm{~kg} / \mathrm{ha}$. Waktu aplikasi POC belum mampu meningkatkan bobot kering tanaman. Penelitian serupa juga menjelaskan bahwa pemberian interval waktu pupuk organik cair memberikan perbedaan yang tidak nyata $(\mathrm{P}>0,05)$ terhadap bobot kering tanaman sorgum karena pasokan unsur hara dari POC belum mampu meningkatkan pertumbuhan tanaman (Bachtiar \& Refina, 2013). Bobot tanaman kering menunjukkan aktivitas tanaman dan kandungan air jaringan, unsur hara dan hasil metabolisme tanaman (Aisyah et al.,2011).

\section{KESIMPULAN}

Perlakuan konsentrasi dan waktu aplikasi POC kulit pisang secara mandiri belum mampu meningkatkan semua variabel pertumbuhan dan hasil tanaman kumis kucing secara nyata. Tidak terjadi interaksi antara konsentrasi dan waktu aplikasi POC kulit pisang kepok terhadap semua variabel pertumbuhan dan hasil tanaman kumis kucing.

\section{DAFTAR PUSTAKA}

Agussimar. T. (2016). Pengaruh konsentrasi dan interval waktu pemberian pupuk organik cair (POC) nasa terhadap pertumbuhan bibit kakao (Teobroma cacao L). Skripsi. .Fakultas Pertanian, Universitas Teuku Umar Meulaboh, Aceh Barat.

Aisyah. S., Sunarlim, N. \& Solfan, B. (2011). Pengaruh urin sapi terfermentasi dengan dosis dan interval pemberian yang berbeda terhadap pertumbuhan tanaman sawi (Brassica juncea L). J. Agroekoteknologi,2,1-5. DOI: http://dx.doi.org/ 10.24014/ ja.v2i1.127.

Apitriani.M, Riastuti, R.D., \& Susanti, I. (2016). Pengaruh pemberian pupuk organik kulit pisang jantan terhadap pertumbuhan dan produktivitas tanaman Tomat (Solanum iycopersicum.L). Skripsi. Biologi STKIP PGRI, Lubuk Linggau.

Bachtiar. T. \& Refina, E. (2013). Pengaruh Pupuk Organik Cair terhadap Kontribusi Nitrogen yang Ditentukan dengan Teknik Isotop N dan Pertumbuhan Tanaman Sorghum (Sorghum bicolor L.). Prosiding Seminar Nasional Matematika, Sains, dan Teknologi. FMIPA-Universitas Terbuka.

BPOM RI. 2004. Kandungan daun Kumis Kucing. Badan Pengawas Obat dan Makanan Republik Indonesia, Jakarta. 
Damanik, Bactiar, Fauzi, Sarifuddin, \& Hamida. (2011). Kesuburan Tanah dan Pemupukan. USU Press., Medan.

Departemen Kesehatan RI. 2006. Kebajikan Obat Tradisional Nasional. Kotranas,Jakarta.

Daryanti. \& Dewi, T.S.K. (2017). Pengaruh berat media dan interval pemberian pupuk cair terhadap pertumbuhan dan hasil tanaman Pakchoy dalam polibag. Jurnal Ilmiah Agrineca. 17(2), 1-11.DOI:https://doi.org/10.36728/afp.v17i2.641.

Hajoeningtijas. D.O. \& Budi, G.P. (2008). Pengaruh bahan pembenah tanah terhadap kuantitas dan kualitas terhadap tanaman kucing (Orthosiphion arisatus Bl.(Miq) dengan budidaya organik. J.AGRITEK, . 10, 18-29.

Hariuddin, R. (2012). Pengaruh berbagai konsentrasi ekstrak daun gamal sebagai sumber mikro-organis me lokal terhadap pertumbuhan tanaman nilam (Pogostemon cablin benth). J. Dinamika, 19-31.

Husic. M. \& Cicic, M. (2009). Luxury consumtion factors. $J$ of Fashion Marketing and Management, 13(2), 231-245.

Jumini, Harsinah \& Armis. (2012). Pengaruh interval waktu pemberian pupuk organik cair enviro terhadap pertumbuhan dan hasil dua varietas mentimun (Cucumis sativus L.). J. Floratek, 7, 133-140.

Makmur \& Magfirah. (2018). Respon berbagai dosis pemberian pupuk organik cair terhadap pertumbuhan dan perkembangan cabe merah. $J$. Gulung Tropika, 7(1), 1-10.

Manullang, G.S., Rahmi, A. \& Astuti, P. (2014). Pengaruh jenis dan konsentrasi pupuk organik cair terhadap pertumbuhan dan hasil tanaman sawi (Brassica juncea L.) Varietas Tosakan. Agriculture and Forestry, 13(1), 33-40. DOI: https://doi.org/10.31293/af.v13i1.545.

Masayu. (2015). Pengaruh Konsentrasi Pupuk Organik Cair Kulit Pisang terhadap Pertumbuhan dan Hasil Kedelai (Glycine max (L) Merril). Skripsi. Sekolah Tinggi Ilmu Pertanian Graha Karya, Muara Bulian.

Muldiana, S. \& Rosdiana. (2017). Respon tanaman terong (Solanum malongena L.) terhadap interval pemberian pupuk organik cair dengan interval waktu yang berbeda. Prosiding Seminar Nasional Pertanjian dan Tanaman Herbal Berkelanjutan di Indonesia, Universitas $\mathrm{Mu}-$ hammadiyah, Jakarta.

Munir J, Erianto \& Fatimah. (2017). Response of red onion (Allium Cepal.) On time interval and type of liquid organic fertilizer. J. Bibiet, 2(1), 27-36.DOI:http://doi.org/10.22216/jbbt.v2i1. 2438.

Nasrun, Jalaludin, \& Herawati. (2016). Pemanfaatan limbah kulit pisang barangan sebagai bahan pembuat pupuk cair. J. Teknologi Kimia. 5(2), 19-26. DOI: https://doi.org/10.29103/jtku.v5i2. 86.

Nasution, J.F., Mawarni, L. \& Meiriani. (2014). Aplikasi pupuk organiak padat dan cair dari kulit pisang kepok untuk pertumbuhan dan produksi tanaman sawi (Brasica juncea L). J. online Agroekoteknologi. 2(3), 1029-1037.

Nurhasana. (2011). Pengaruh Pupuk Organik. Penebar Swadaya, Jakarta.

Nugraha, D. (2013). Kandungan unsur hara kompos dari campuran kulit pisang dan effective microorganisme 4. Budidaya Tanaman Perkebunan. Jurusan Manajemen Pertanian Politeknik Pertanian Negeri Samarinda, Samarinda.

Palupi, P. N. (2015). Karakter kimia pupuk cair asal limbah kulit pisang kepok dan pengaruhnya pada tinggi tanaman kedelai. J. AGRIFOR, 14(2), 239-244.DOI:https://doi.org/10.31293/af.v14i2. 1431.

Pardosi, A.H., Irianto \& Mukhsin. (2014). Respon tanaman sawi terhadap pupuk organik limbah sayuran pada lahan kering ultisol. Prosiding Seminar Nasional Lahan Suboptimal. Universitas Jambi, Jambi.

Parawansa. I.N.R \& Hamka. (2014). Interval waktu pemberian pupuk organik cair urin sapi pada pertumbuhan dan produksi tanaman kangkung darat (Ipomoea Reptans Poir). J. Agrisistem, 10(2), 170-178.

Pribadi. R.E., Wawan, L \& Bagem.S.S. (2014). Prospek perbaikan teknologi budidaya Kumis Kucing di Kabupaten Sukabumi. Balai Penelitian Tanaman Rempah dan obat. J. Littri, 20(4), 211-219. DOI: http://dx.doi.org/10.21082/littri.v20n4. 2014.211-219.

Rajak. O, Patty, J.R. \& Nandesa, J.I. (2016). Pengaruh dosis dan interval waktu pemberian pupuk organik cair BMW terhadap pertumbuhan dan produksi tanaman sawi (Brassica juncea L.). J. Budidaya Pertanian, 12(2), 66-73.

Rochman, M \& Nurwiati, S. (2005). Intisari Biologi. Pustaka Setia, Bandung.

Rosliani, R. \& Basuki, R.S. (2012). Pengaruh varietas, status K-tanah, dan dosis pupuk kalium terhadap pertumbuhan, hasil umbi, dan serapan hara $\mathrm{K}$ tanaman bawang merah. J. Hort., 22(3), 233241.DOI: $\quad$ http://dx.doi.org/10.21082/jhort. v22n3.2012.p233-241.

Rostiana, O. (2012). Respon Dua Eksesi Tanaman Kumis Kucing (Orthosiphion Arisatus Bl.Miq) Terhadap Perlakuan Pemupukan di Dataran Tinggi. Balai Penelitian Tanaman Rempah dan Obat. Pusat Biofarmaka Institut Pertanian Bogor, Bogor. 
Safei. A.M. (2018). Pengaruh Dosis dan Waktu Aplikasi Pupuk Cair Bioslurry Terhadap Pertumbuhan dan Produksi Tanaman Kacang Tanah (Arachis hypogaea L.). Skripsi. Fakultas Pertanian Universitas Lampung, Lampung.

Saragih. F.E. (2016). Pengaruh Pupuk Cair Kulit Pisang Kepok Terhadap Pertumbuhan Tanaman Sawi (Brassica juncea L). Skripsi. Fakultas Keguruan dan Ilmu Pendidikan Universitas Sanata Dharma, Yogyakarta.

Sari. M.P. (2016). Pengaruh Penggunaan Pupuk Organik Cair dari Limbah Kulit Pisang Kepok Terhadap Pertumbuhan Tanaman Bayam (Amarantus tricolor L). Skripsi. Prodi Biologi Fakultas Keguruan dan Ilmu Pendidikan Universitas Lampung, Lampung.

Sitompul, S.M. \& Guritno, B. (1995). Analisis Pertumbuhan Tanaman. Gadjah Mada University Press., Yogyakarta.

Sitorus, U.K.P., Siagian, B. \& Rahmawati, N. (2014). Respons pertumbuhan bibit kakao (Theobroma cacao L.) terhadap pemberian abu boiler dan pupuk urea pada media pembibitan. Jurnal Online Agroekoteknologi, 2(3), 1021-1029.

Wahyono, B. (2008). Ilmu Pengetahuan Alam. Pusat Perbukuan Depdiknas, Jakarta. 